\title{
Critical Political Thingking Kartini through Education
}

\author{
Ufi Saraswati $^{1}$, Giri Harto Wiratomo ${ }^{2}$, Natal Kristiono ${ }^{3}$ \\ \{ufisaraswati1966@gmail.com¹, girihartowiratomo@mail.unnes.ac.id ${ }^{2}$, \\ natalkristiono@mail.unnes.ac.id $\left.{ }^{3}\right\}$
}

Universitas Negeri Semarang ${ }^{1,2,3}$

\begin{abstract}
Kartini's figure became a central icon in the study of education for women. Based on Bernhard Lewis's opinion, there are three different histories, namely remembered history (recovered history) and recovered history, and invented history. Similarly, when reviewing women in their views and ideals, especially Kartini. Discussions about the views and ideals of women in this matter are certainly inseparable from the journey of women themselves in the course of history. The formulation of the problem of this research is how Kartini's views and ideals in Indonesian independence through education? This research method uses the history method. The results of the analysis and discussion of this article are that women's history is actually as old as human existence on earth, but attention to women's issues in scientific disciplines, including in history, only started since the 1970s when feminism entered the world of science. From that moment the influence of feminism began to become a topic of discussion in society. This social difference between men and women is often a problem in the view of society, including how the role of women in their views and ideals for their nation. Women and their roles are called 'fighters' to be interesting, when placed in such a way in the context of the struggle for their nation. 'Fighting' as a masculine word gives a signal about the real position of women as women fighters, especially those in Central Java. One of the roles of women fighters in achieving their aspirations towards independence and filling the independence that has been achieved through education. Among these female combatants are women named Kartini. Kartini's struggle for her nation was not through physical resistance, but by advancing women in the field of education. The struggle of the Kartini movement which championed the position of women who were as high as men at the milestone of the National Awakening in 1908 with their progressive views provided a discourse of awareness of the importance of education in the realm of independence.
\end{abstract}

Keywords: Views, Ideals, Female Fighters, Education.

\section{Introduction}

Women in society are always associated with nature and men are associated with culture. Women are associated with nature because in addition to women's physiology and reproductive functions make women closer to nature, also because of women's involvement in reproductive activities. Women tend to be seen in limiting certain social functions and are also seen as close to nature, such as breastfeeding and caring for children, including women who first taught the child at an early age to socialize. While men are associated with culture because they have to find a means of creating culture, namely with technology and symbols.

Biological differences between men and women are essentially nothing to question. It is not a problem also if women because of their nature must give birth and breastfeed and care for 
children. The problem arises if these biological factors are constructed socially and culturally by patriarchal constructions so as to give rise to gender differences and the role of gender in society which gives rise to gender injustice. The definition of gender is the result of sociocultural construction consisting of the characteristics, attitudes, and behavior of a person who can be learned according to their socio-cultural environment, so that someone will adjust according to their gender. As a man learns how to behave and behave according to what is said to be appropriate for men and a woman learns how to behave and behave according to what is said to be appropriate for women. Feminine character for women and masculine for men is thus determined by the socio-cultural environment.

History records the role of women in politics. Indonesian women have played a role in the political field long before Western colonialism. The names that should be noted include Ratu Sima, Sanggramavijaya, Dharma Prasada Tunggadewi (Erlangga's right hand) and a series of names that are well known throughout Indonesia. Gender equality between women and men in a historical perspective is actually not new. Indonesian women during the Old Mataram period until the time of Majapahit had gained an equal position and role with men in various aspects of life. In the Old Javanese era, Titi Surti Nastiti in her dissertation entitled "Position and Role of Women in Old Javanese Communities of the 8-15 AD" said that in the Old Javanese period women and men had equal opportunities even though in terms of quantity not as many as men man. According to Nastiti, it was further stated that equality can be achieved in gaining public office, social activities, the economy, the arts, and others. At the end of the nineteenth century Indonesian society began to change drastically, as new scholars for indigenous employees, aristocratic children, in direct contact with a number of ideas Nationalism as a logical result of the ethical political system applied by the Dutch in its colonies. The emancipation movement is far more diverse than the word "Nationalism". Economic and religious reasons felt more important and dominant in various movements including the women's movement. The initial activities of women's organizations which were originally only limited to household activities and skills education began to develop towards the ideals of Independence.

In the 1920s, for the first time in Indonesian history women moved beyond their gender interests. They took the form of socio-cultural problems of women and organized themselves on the basis of religion and region and important political movements at that time. Various women's schools were established, and a number of magazines were published, a series of actions on behalf of women laborers and prostitutes were launched. The first formal women's organization was Poetri Mardika, which was established in Jakarta in 1912. This organization fought for education for women, encouraged women to appear in public, discarded the feeling of "fear", and "raised" women to the same position as men.

Throughout the country at that time resistance emerged, but the Netherlands always won because its superiority in the field of weapons and political capabilities of its race (Devide et Impera) which sufficiently made these local rulers deceived. In various parts of Indonesia during this period we met many prominent women who appeared to defend the country such as Cut Nyak Dhien and Cut Meutia, both from Aceh, Raden Ayu Ageng Serang and Roro Gusik wife of hero Untung Surapati, Christina Martha Tiahahu from Maluku, Emmy Saelan from South Sulawesi. They all struggled to take up arms against Dutch colonialism to defend sovereignty even though it was still limited to their own country. It was only in the early 20th century that female warriors began to focus on their struggle to make education available to women. In the following decade, more and more women were actively involved in the long struggle for independence to obtain equality in education as well as men.

\section{Result and Discussion}




\subsection{The Importance of Education for Women}

Since before independence until after independence, awareness of women's education in Indonesia cannot be separated from the growth and development of awareness and activity of the feminist movement in Indonesia. Historically awareness of the importance of women's education in Indonesia can be grouped into several developments, namely awareness of bumiputera figures, awareness of Dutch figures, women's and social organizations and nongovernmental organizations. Awareness of the importance of the education of women from the bumiputera community was spearheaded by Kartini, Dewi Sartika, Roehana Koedoes, Rahmah El Junusiah, the Aisyiyah organization led by Siti Walidah and Tamansiswa. Kartini and Dewi Sartika came from a noble family so the two had the opportunity to take basic education in the Dutch colonial period.

Western influence began to enter Javanese society in the late 19th century and the beginning of the 20th century. The regents or nobles, whose numbers are still small in the area of Central Java who have been educated and think ahead, include the Regent of Demak R.M.A.A. Hadiningrat, Regent of Jepara R.M. Adipati Sosroningrat, Regent of Pati P.A. Condronegoro is known for writing about the story of travel on Java and several of his essays published in the magazine Lembaga Kebudayaan. The Holy Regent also invited Dutch teachers to educate their sons. In 1902 there were several regents who were good at writing and communicating in Dutch, including Akhmad Jayadiningrat, Regent of Serang, R.M.A.A. Hadiningrat, Regent of Demak, and R.M. Duke of Sosroningrat.

In 1899, R.M.A.A. Hadiningrat published the results of an investigation report regarding the cause of the regent's authority in the eyes of the people. According to him, the error lies because of the lack of educational opportunities for the Javanese. Regents who were not Western educated were not considered by the Dutch authorities, which caused a loss of authority and showed an inferiority complex. Hadiningrat suggested that in the future be given the opportunity for higher school education, to prospective regents. The Regent of Hadiningrat also fought in the appointment of civil servant employees, that rights and education were not merely descendants and blood.

The birth of women's movements in Indonesia, especially Central Java, was inseparable from the role and spirit of the daughter of the Jepara Regent, namely R.A. Kartini (April 21, 1879-September 17, 1904). Kartini was born on April 21, 1879 as the fifth descendant of Raden Mas Adipati Ario Sosroningrat, as Regent of Jepara who ruled 1880-1905. Kartini was born when her father served as Wedana in Mayong, Jepara Regency. Kartini experienced education until graduating from ELS (Europeesche Lagere School) in Jepara but did not succeed in continuing her studies at HBS (Hoogere Burger School) Semarang, because she was not allowed by her father. At that time Kartini was 12 years old, considered to be "Young Women", the age at which adat must begin "on the edge".

The spirit of Nationalism possessed by R. A. Kartini began to emerge since Kartini was still a teenager and increasingly undaunted when Kartini often sent letters with friends who were abroad. In these letters, R. A. Kartini devoted all his ideals and ideas. Like the letter addressed to Mrs. Abendanon on August 25, 1903. Kartini in the letter wrote that Kartini's ideas were supported by the family and the community there. Sometimes Kartini forgot to think about Kartini's own future, because Kartini was too concerned about the fate of the people out there. Kartini dreamed that someday, she would become an older sister or a mother for people who were outside the palace. 
During his life at school, Kartni had many Dutch children and became acquainted with Western thought and knowledge. The impression he gained as he grew older and the books he read, gave Kartni the belief that the position of women was very low, so he aspired to become a teacher for the children of the regents. Daughters of nobles must guide and lead women to progress. However, unfortunately the proposal to establish the school was rejected by the Dutch East Indies Government at the insistence of the objected regents. In Jepara Regency, Kartini herself got a study room, a place to read and write letters to her acquaintances, most of whom were in the community. In addition, Kartini prior to marriage had carried out her dream by establishing a small school in the district for the children of civil servants. Among his friends sent letters were Dutch people belonging to an ethical group within a government such as J.H. Abendanon was a Director of the Education Department in 19001905 in the Netherlands. The letters written by Kartini about association in the environment, the backward conditions of the people and the misery of ancient customs, such as the respect and seclusion of girls, marriages are degrading to women. Kartini also criticized Dutch officials who did not respect the regents and delayed the expansion of education for the bumiputera people because they were considered to endanger the position of the Dutch East Indies government.

Kartini's letters were published for the first time in 1911, after his death. The letter was published by Mr. and Mrs. Abendanon under the title "Door Duisternis tot Licht" (After Darkness Revealed). In 1923 the book was printed for the fourth time and translated into Indonesian, English, Arabic and French. The purpose of the publication was to get funding to establish girl schools and female teacher schools in Indonesia. In 1921 Fonds Kartini was founded in Den Haag to finance the Kartini School in Dutch as an introduction to school in Semarang, Jakarta, Malang, Bogor, and with regional languages in Cirebon, Rembang, Pekalongan, Indramayu, and Surabaya. In 1912 the first Kartini School was opened in Semarang at the encouragement of Mr. Deventer. Then stood "Van Deventer Fonds", the goal was the same as Fond Kartini for the secondary school level, and the Van Deventer teacher school in Semarang was one of the results of this activity. The letters and establishment of schools from Kartini in various places, made it inseparable from the movement of women.

\subsection{Development of the Position of Indonesian Women Bumiputra women during colonialism}

Dutch East Indies colonialism cannot be separated from the history of plantation capitalism, replacing VOC colonialism which controls port areas. The period of Dutch East Indies colonialism began in the early 19th century with Java as a major part of the penetration of Dutch colonial power [1]. Under the auspices of colonial rule there were repressive actions against Indonesian society and social stratification was deliberately created to further oppress the Indonesians, especially women, in addition to provoking racial jealousy with the aim of dividing the colonial people as well as racial discrimination.

The number of European women who were very little compared to the number of men at that time became a logical trigger for the increasingly rolling form of concubinage, which had been pioneered during the period of VOC colonialism. It must be acknowledged that the first sexual needs presented Nyai (indigenous housekeeper) in the plantation areas. As for the socalled Nyai, it is women who are maintained by wealthy colonial and private Dutch officials. Before the Dutch arrived, Asian and Portuguese traders were used to maintaining Nyai. During the VOC the Dutch who married Bumiputera women could not bring their wives and children from the marriage to their home country, the marriage was considered illegal by the Dutch 
church. This event prompted the Company people to just keep Nyai-Nyai, which they could leave at any time.

Most of the women who became Nyai came from farm families and other lower-class families who were sold by their parents to meet family needs. There is also Nyai from a priyayi family. Nyai who came from a priyayi family was usually handed over by his father to the Dutch or other Europeans to secure his father's position and position. When a woman is Bumiputera being Nyai, the economic life automatically becomes better. He lives more comfortably, besides being more "respected" than before. In the eyes of ordinary people, he was not considered part of them. Hidden hatred among the people towards white people (racial prejudice) makes women make bumuputera women into Nyai forced to bear the hatred of their people, because they are considered traitors. In this culture, it was seen that women in the colonial era were judged to be nothing more than goods, and women's discrimination was mostly carried out by domestic and foreign parties, and social inequalities caused Indonesian women to be subjected to discrimination as well as families who were more concerned with social positions. than their daughter [1].

Women's Organization in the Independence Period Indonesia after the Proclamation of 17 August 2017 was faced with efforts to defend independence from the threat of the Allies who wished to re-establish Dutch rule in Indonesia. Allied Forces Netherlands East Indies (AFNEI). In the beginning the arrival of the Allied forces was responded to neutrally by the Indonesian side. After it was discovered that the arrival of Allied forces intended to ride the Netherlands Indische Civil Administration (NICA), which openly wanted to re-establish power in the Dutch East Indies, the attitude of Indonesia began to change [2].

One example of the participation of the struggle of women's movements in defending Indonesian independence in 1945 was the battle that took place in Surabaya. The Battle of Surabaya was the fiercest battle, on November 10, 1945, because all the people, especially the young Surabaya people, refused General Mansergh's ultimatum and Allied troops to surrender all weapons. Indonesian women in such an atmosphere felt called to participate in fighting to defend and defend independence. The independence fighters gathered cadres so that they were prepared to hold resistance to the barrier to independence, this struggle was fully supported by the people, including the youth, so that the Army of the Republic of Indonesia (PPRI) under the leadership of Lukitaningsih [3] emerged. ) PPRI also has the duty to provide first aid kits or nurses to soldiers who have been injured while dealing with the Allies and supply food at the front post of the battle. This continued even more and more tasks were carried out by women due to the needs of the role of all elements of society until the withdrawal of troops and people from the Surabaya area on November 28, 1945.

The struggle of women in Surabaya is accommodated by the formation of the Youth of the Republic of Indonesia (PPRI) in early September 1945 at the Indonesian National Building (GNI) Jalan Bubutan Surabaya. The effort carried out by PPRI was the action of raising a red and white flag in homes, in the offices of all corners of the city which were still controlled by Japan, the PPRI also took part in holding scribbled actions, plaques attachments, red and white leaflets and also sewing the BKR epaulette and TKR. In addition to PPRI, there are also wellknown women's organizations at that time including "PERWANI" (Indonesian Women's Association) and "WANI" (Indonesian Country Women). As in the national independence struggle, the men of the National leader actively sought support from women. In the 1945 Constitution of the Republic of Indonesia explained that, women are guaranteed legal and political rights just like men so that women gather together to support the ideals of the National struggle. During the period of independence of the Republic of Indonesia, the movement of 
women's organizations was more active in building and placing women as well as strengthening newly independent countries.

In subsequent developments in February 1946 the Congress of women's organizations was held in Solo, with the results of its Congress being the fusion of two women's organizations namely the Indonesian Women's Association (PERWANI) and the Indonesian State Women (WANI) into a fusion body called the Women's Association of the Republic of Indonesia (PERWARI) [4]. In the situation and conditions of the physical struggle as well as in the sociopolitical field, the women's movement organizations began to improve themselves in order to be able to garner strong unity and unity by forming the Indonesian Women's Congress Agency (KOWANI) in early June 1950 in Surabaya. The Indonesian Women's Congress (KOWANI) is chaired by Nyai Puger, with the vice chairman being held by Mrs. Dr. Nitisastra numbers, as well as the author Ny. Irang, and extraordinary member Ny. Samadikun [5].

After the emancipation of women was echoed, many women's associations emerged in Indonesia such as PERWANI (Indonesian Women's Association). PERWANI is a women's association that is very popular in Indonesia. Many of the efforts or activities carried out by PERWANI, and one of them is by holding a Congress. At the initiative of the Yogyakarta branch of PERWANI led by Mrs. D.D. Susanto, the First Women's Congress after the independence proclamation was held in Klaten, Central Java on December 15-17, 1945, chaired by Mrs. Kartowijono and Mrs. Maria Ulfah Santoso. At the meeting, PERWANI and other women's associations merged into one in an organization called PERWARI (Indonesian Women's Association).

The next meeting was held in Solo on February 24-26, 1946. At the meeting it was decided to make a permanent organization called the Indonesian Women's Congress Agency (KOWANI) consisting of PERWARI and PPII, Indonesian Christian Women Association from Protestants, and the Catholic Party women's section Indonesia. KOWANI has the power of attorney to make decisions concerning the interests of the associations in it. The second congress of Indonesian women was not held in Central Java, but in Madiun, East Java. In the Congress which was held from June 14 to June 16, 1946 and was attended by thirteen representatives from each association and decided that they would help the Republican army in every way to fight the Dutch. They take the initiative to form public kitchens and fight in the vanguard in handling this kind of activity.

The 3rd KOWANI Congress was held in Magelang, Central Java on 14-16 July 1946 led by Mrs. Soenarjo Mangoenpoespito. The meeting was held after eight months of the Linggarjati agreement on 15 November 1946. At that time, the Netherlands de facto recognized the Republic of Indonesia as a federal state which was still under the supervision of the Netherlands. Political instability took place at that time, so the Congress decided to send a letter of appreciation for the progressive association of women in the Netherlands who regretted sending Dutch troops to Indonesia. After the Congress ended, Dutch forces launched their military aggression.

In 1948 after the declaration of the Declaration of Human Rights was established by the United Nations, the struggle of women to realize gender equality and justice began to be actively carried out. Global issues that have attracted the world's attention, especially after the end of the cold war between the Western and Eastern Blocs. These changes are in line with the shift in the development paradigm from the security and stability approach to prosperity from the production approach to a more democratic human approach. The 4th KOWANI Congress held in Solo on August 26-28, 1948 led by Mrs. Soepeni Poedjoboentoro agreed to base all their activities on the five basic principles of Pancasila. The Dutch military aggression that occurred in Yogyakarta hampered communication from Indonesian women's associations. Through their 
strong determination and initiative to hold a conference. The KOWANI conference was held in Yogyakarta on September 2, 1949, chaired by Mrs. Soepeni. The conference was known as "Indonesian Women's Association". The conference was attended by delegates from all regions who were free or still under the Dutch government and 82 women's organizations from all over Indonesia. The biggest evidence of the enthusiasm of these women, seen by their desire to unite, that this conference was held in a divided country into two even destroyed and completely deficient.

Before the Round Table Conference, the most important thing that was arranged was absolute loyalty to the leaders who would negotiate and support them to a republic that was not separate. The delegates also formulated basic demands as a future vision. KOWANI's support for the nation, proves that Indonesian women contribute significantly and meaningfully to the nation's struggle. The role carried out includes all aspects of activities that can be done by his people. All obstacles were ignored by Indonesian women because of the urgent situation, such as in Aceh and South Sulawesi, where women's movement was very limited due to the strict provisions of custom, law and religious regulations. Even the spirit of women to get equal rights and defend the nation must continue to be conveyed to the women of Central Java and this nation to this day.

\section{Conclusion}

Talking about women is inseparable from the concept of emancipation, because this is precisely the central theme of the long debate. The oppression of women is considered to deny the essential values of divine giving and is a deviation from the dignity of women themselves, which is why emancipation movements that evenly equalize the rights of men and women emerge. Emancipation movements in Indonesia were formed because they were driven by previous events in the history of the struggle and movement of the Indonesian nation. It is appropriate if the desire and encouragement to advance women comes from the women themselves. They no longer feel satisfied with a limited way of life filled with family and household obligations, they want to get freedom and work in a wider environment. The struggle of the pioneers of the women's movement still maintains and nurtures elements in their own culture, especially regarding life attitudes and morality. As the most important source for investigating what values are supported by leaders regarding Western education, but upholding indigenous culture is what is contained in the collection of RA letters. Kartini. The equal position of citizens in the field of law and government as confirmed in Article 27 paragraph 1 of the 1945 Constitution also has implications for the equality of opportunities for women and men to hold positions in government apparatus.

\section{References}

[1] L. Hadiz, "Perempuan dalam wacana politik orde baru," Pilihan Artik. Prism. LP3ES, Jakarta, 2004.

[2] P. M. Djoened and N. Nugroho, "Sejarah Nasional Indonesia VI," Jakarta: Balai Pustaka, 1993.

[3] H. N. Irna, Lahirnya Kelaskaran Wanita dan Wirawati Catur Panca. Jakarta: Yayasan Wirawati catur Panca, 1992.

[4] AD/ART, “Anggaran Dasar/Anggaran Rumah Tangga dan Program Umum PERWARI Tahun 2004-2008." 
[5] N. Soewondo, Kedudukan wanita Indonesia: Dalam hukum dan masyarakat. Ghalia Indonesia, 1984. 